\title{
T-Cell Surface Glycoprotein CD3 Gamma
} Chain

National Cancer Institute

\section{Source}

National Cancer Institute. T-Cell Surface Glycoprotein CD3 Gamma Chain. NCI

Thesaurus. Code C38901.

T-cell surface glycoprotein CD3 gamma chain (182 aa, $20 \mathrm{kDa}$ ) is encoded by the human CD3G gene. This protein plays a role in T-cell receptor-mediated signaling. 